\title{
Detection and Identification of Infectious Bursal Disease Virus in Broiler Farms in Sulaimani Province
}

\author{
Dr. Nawzad A. R., Dr. Nahla M. S., Dr. Shilan F. M., and Dr. Zana H. Mahmood
}

\begin{abstract}
The bursal Infectious disease (IBD) is an acute and highly contagious viral infection of immature chickens. A total of 76 poultry farms in areas around Sulaimania region was sampled to investigate the infection with the infectious bursal disease in broiler chickens. Out of 76 poultry farms, $28(36.8 \%)$ were infected with IBD during the period from October 2012 to March 2013. The significant clinical symptoms were a sudden drop in feed and water consumption, severe depression, watery white droppings and high mortality, at necropsy, there are hemorrhages in leg muscles, degeneration of the pectoral muscle, white mass (urate deposit) in the kidneys and cloaca are frequently observe during a post-mortem examination. Also, hemorrhagic \& swollen bursa filled with strawcolored fluid was identified in few cases. Histopathology revealed hyperplasia of the reticuloendothelial cells and expansion of interfollicular connective tissue with edema of the affected bursa of Fabricius. The nucleotide sequence of Sulaimani IBDV isolates showed \%99 homology and they also showed \%96-\%99 similarity with other IBDV strains. Regarding phylogenetic tree, construction based on the VP2 hypervariable region of IBDV nucleotide sequence alignment of the 16 genomes. IBD virus was divided into two general groups, namely Very virulent 1 (VVI) and Very virulent two (VVII). The topology of the tree indicated that the field isolates Sulaimania 01, 2012 and Sulaimania 022012 belong to very virulent IBDV strains that contain Indian and Egyptian Isolate.

An outbreak of infectious bursal disease affecting 20-45 days old broiler chickens was investigated for the first time in Sulaimani region. This research is the first occurrence of infectious bursal disease in Sulaimania region/Iraq by RT-PCR.
\end{abstract}

Keywords - IBD, Symptoms, Histopathologypathology, RT-
PCR.

\section{INTRODUCTION}

Infectious bursal disease (Gumboro disease), is highly contagious and immunosuppressive disease of immature chickens caused by an infectious bursal disease virus (IBDV) which is under the genus Avibirnavirus and is a member of the family Birnaviridae and is responsible for significant economic losses in the poultry industry worldwide [1]-[2]. The genome

Nahla Muhammad Saeed, College of Veterinary Medicine, University of Sulaimania, Iraq,

Nawzad Rasheed Abdulrahman Dalaw, College of Veterinary Medicine, University of Sulaimania, Iraq,

Shilan Faqe Muhammad Salih, College of Veterinary Medicine, University of Sulaimania, Iraq.

Zana H. Mahmood, College of Infection and globel health, University of Liverpool, UK. of an Infectious bursal disease virus (IBDV) and other Birnaviruses consist of double-stranded RNA (two segments), which are packaged in a nonenveloped icosahedral shell $60 \mathrm{~nm}$ in diameter [3]-[4]. The largest part, A, is 3,261 nucleotides long, and it encodes an $110-\mathrm{kDa}$ precursor protein in a large single open reading frame (ORF), which is cleaved by autoproteolysis to yield mature VP2, VP3, and VP4 proteins [5]. The major structural proteins of the virion are VP2 and VP3 while VP4 is a minor protein share in the processing of the precursor protein single-shelled, [4]-[6]. The major protective antigen of IBDV is the VP2 protein that contains specific epitopes responsible for inducing neutralizing antibody responses [7]. Variations in antibody recognition may occur due to changes in an amino acid within the variable region of VP2, as well as, antigenicity, immunogenicity, virulence, and tissue tropism of IBDV strains [8]-[9]. The smallest segment, B, is 2,827 nucleotides long, and it encodes VP1, a 97-kDa protein having RNA-dependent RNA polymerase activity [4]-[10]. The infectious bursal disease virus has two serotypes; however, only serotype I viruses are naturally pathogenic to chickens [12]-[13]. Serotype I strains are classified as very virulent IBDV strains, classic or variant and differ in their virulent, antigenic, and pathogenic properties [14]-[15]. A second serotype (serotype II), isolated from a fowl, turkeys, and ducks. The two serotypes can differentiate by cross-neutralization assay [16]-[17], and ELISA using monoclonal antibodies [18]-[19]. Gumboro disease causing economic losses to the poultry industry worldwide [20]. The target organ of IBDV infections is the cloaca bursa. However, the replication of IBD viral occurs in other lymphoid structures, including the spleen, thymus, Harderian gland, and cecal tonsils [21]. Serotype I strains are considered pathogenic because they cause lymphocytic depletion and lesions in the bursa of Fabricius (BF) of susceptible chicken strains. While serotype II considered no pathogenic because no lesions in the $\mathrm{BF}$ are detected after infection of susceptible chickens with serotype II strains, [22]. The immunosuppressive effects of IBDV infections enhance the chicken's susceptibility to secondary bacterial infections such as gangrenous dermatitis, E. coli infections, with a viral infection like chicken anemia agent, inclusion body hepatitis, respiratory diseases. IBDV infections also interfere with effective immune responses to vaccination [23]-[24]-[25]. 
Vaccination is the primary method used for controlling IBD in the poultry industry [26]-[27].

In Iraq and many other countries, the disease picture of IBD is still unclear and requires further investigations. The present study was conducted to investigate suspected infectious bursal disease virus infection among broilers in the Sulaimania region of Iraq, using PCR technique on bursal samples collected from diseased broiler flocks.

\section{MATERIALS AND METHODS}

\section{A. Clinical samples}

During the period from October 2012 to March 2013, data from 76 broiler flocks suspected to be suffering from IBD from Sulaimania districts of Iraq are collected. Detailed information about the total population at risk, the number of birds affected and died, vaccination status and age of affected birds were obtained. Clinical signs and symptoms of the affected birds are noticing. Necropsy examinations were also carried out.

\section{B. Tissue biopsy preparation}

For histopathology the bursae were collected from birds at three days post infection. Tissue sections of 5 micrometers were taken from each paraffin embedded tissue block and were mounted on ordinary glass slides for routine Hematoxylin and Eosin staining for detection of any pathological lesions.

\section{RNA extraction}

Tissue RNA extraction kit (Bioneer, Korea) was used to extract total RNA from 25-40 mg of pooled samples consisting of the spleen, bursa and kidney according to the manufacturer's instructions.

\section{Rt-PCR amplification}

The PCR amplification reaction was carried out in $0.2 \mathrm{ml}$ tubes using AccuPower Rt-PCR PreMix. The reaction mixture consists of $5 \mu \mathrm{L}$ RNA, $1 \mu \mathrm{l}$ (10 pmole) of forward IBD F: TCACCG TCCTCAGCT TAC and $1 \mu \mathrm{l}(10$ pmole $)$ reverse primer IBD R: TCAGGATTTGGG ATCAGC then It is made up of $20 \mu \mathrm{L}$ of DEPC-H2O. The thermocycler was used to incubate the samples and programmed as (initial denaturation at $94^{\circ} \mathrm{C}$ for 5 minutes, followed by 40 cycles consisted of denaturation at $94{ }^{\circ} \mathrm{C}$ for $30 \mathrm{Sec}$, annealing at $55{ }^{\circ} \mathrm{C}$ for 30 minutes and elongation at $72{ }^{\circ} \mathrm{C}$ for $1 \mathrm{~min}$. The final elongation was $72{ }^{\circ} \mathrm{C}$ for $5 \mathrm{~min}$.

\section{E. Electrophoresis and sequencing}

Electrophoresis of PCR products are done on a $1.2 \%$ agarose gel and stained with ethidium bromide then visualized by UV transilluminator. The sizes of PCR products are estimated according to the migration pattern of a 100bp DNA ladder. The amplified size of IBDV was $643 \mathrm{bp}$. The PCR product is sequenced from both ends in Bioneer laboratory in Korea. The DNA sequence is published in the gene bank as, accession number (JX974583) and (JX974582).

\section{F. Sequence comparison and phylogenetic analysis}

VP2 sequence identity of both IBDV isolates (Sulaimania 01 and Sulaimania 02) were determined by blast method at the
National Center for Biotechnology Information (NCBI) Homepage. The nucleotide sequences were analyzed in conjunction with IBDV sequence data from other of Genebank, and the homology percentage were determined. The phylogenic tree was constructed with the VP2 hypervariable region of 13 IBDV isolates of different countries. The Phylogenic tree based on the neighbor-joining method using Kimura2-parameter model in Mega 6. The bootstrap values were determined from 1000 replicates of the original data [26]. There are many of IDBV strain sequences (accession numbers) were used in the analyses: vvIBDV strains - Brazil 2013: JN982255.1, India 2014: KJ547671.1, China 2008: EU328327.1, China 2007: EU042144.1, Iran, 2003: AY323952.1, France 2005: AJ878732.2, China 2012: JX682711.1, Bangladesh 2001: AF362776.1, China 2004: AY598356.1, Iran 2010: AY704912.1, Israel 2008: DQ927042.1, India 2014: KJ699103.1, EGYPT 2000: AF159218.1, and UK66-1 AJ318896.

\section{RESULTS AND DISCUSSION}

The occurrence of the disease: IBD has a worldwide distribution; however, there has been no reported case of the infectious bursal disease in Sulaimania Region/Iraq. Out of 76 broiler farms in and around Sulaimania region/Iraq, tested for the presence of IBDV antigen, it is found that $28(36.8 \%)$, unvaccinated broiler farms were infected with IBDV during October 2012 to March 2013.

\section{A. Clinical and Postmortem findings}

The clinical symptoms were occurring in the third week of age [2]. The most frequent clinical symptoms were; initially dull, depressed, ruffled feathers, severe prostration, yellowish white diarrhea (Fig.1); dropping in feed and water intake, mass death and soiling of the vent, loss of the body. High mortality started on the 3rd day after the onset of the observable symptoms and continued up to the 15 th day.

Ecchymotic hemorrhages were noticed on thigh and breast muscles in the affected birds at necropsy examination (Fig. 2), the presence of gelatinous exudates around Bursa (Fig. 3), or hemorrhages on the serosal surface of Bursa was recorded in the acute form of the disease (Fig. 4). In some of the flocks, hemorrhages at the junction of the proventriculus and gizzard were also recorded (Fig. 5). Nephrosis with swollen kidneys filled with white 'urate' deposits; uraters filled with the white substance and further accumulation of a white stony material in the cloaca.

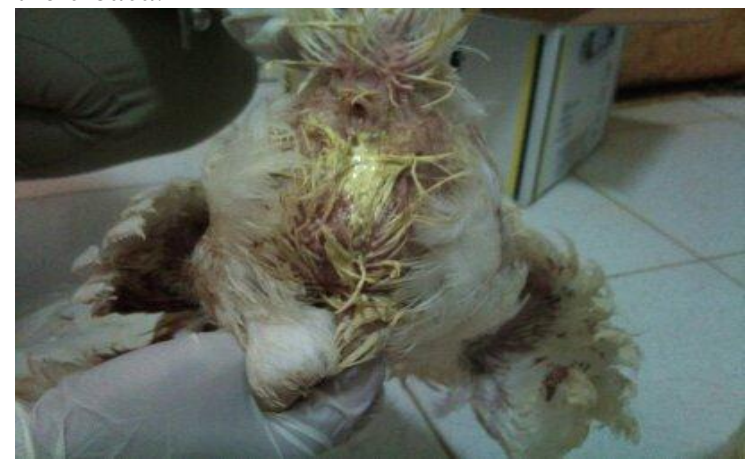

Fig. 1 Bird with whit yellowish white diarrhea 


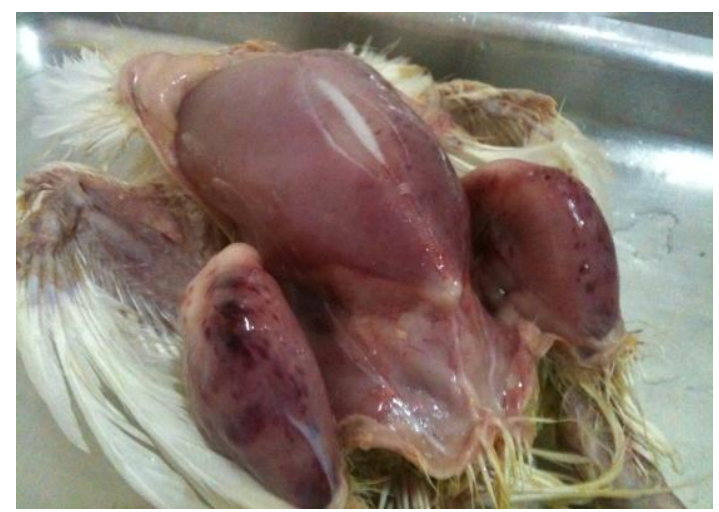

Fig. 2 Hemorrhages on thigh and breast muscles.

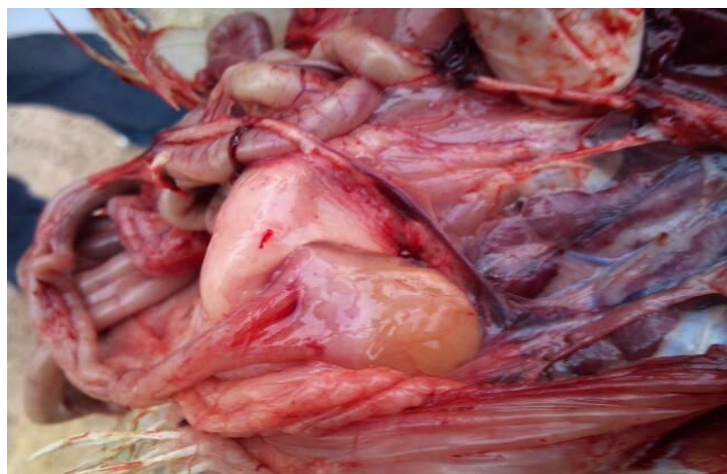

Fig. 3 the presence of gelatinous exudates around Bursa.

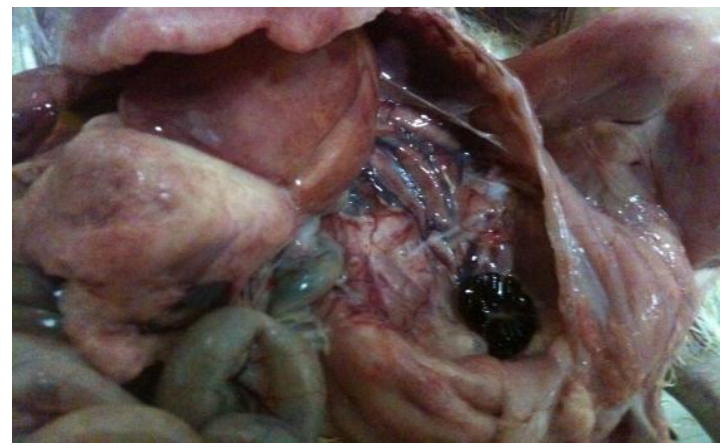

Fig. 4 The presence hemorrhages on the serosal surface of Bursa

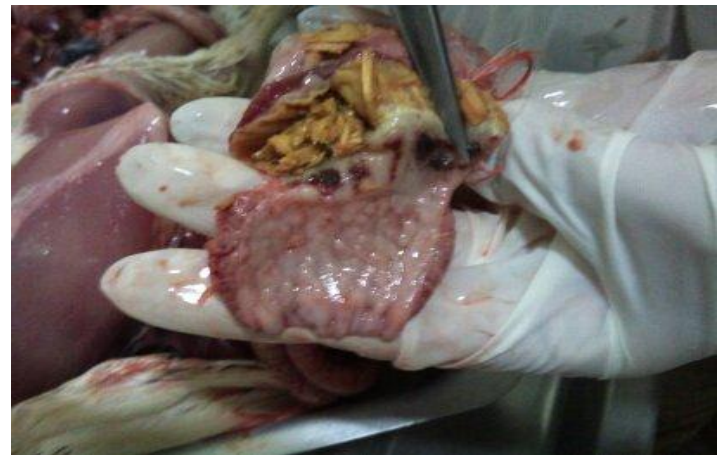

Fig. 5 Hemorrhages on at the junction of proventriculus and gizzard

\section{B. Microscopical findings}

A Section of the bursa of Fabricius there were a loss of the normal corticomedullary architecture of bursa and also the extensive expansion of the interfollicular connective tissue with hemorrhage and edema, cellular infiltration by heterophils, macrophages and plasma cells in addition to medulla necrotic debris (Fig. 6 and 7).

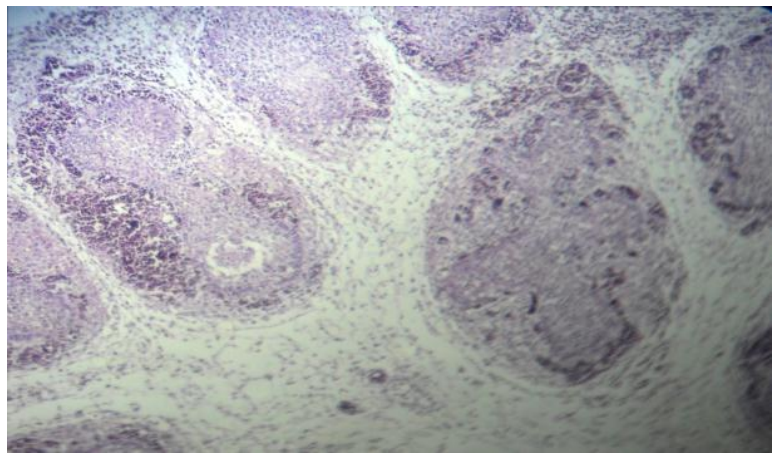

Fig. 6 Marked interfollicular edema, hemorrhage and an inflammatory necrotic lesion in the medullary zone (H\&E 10X).

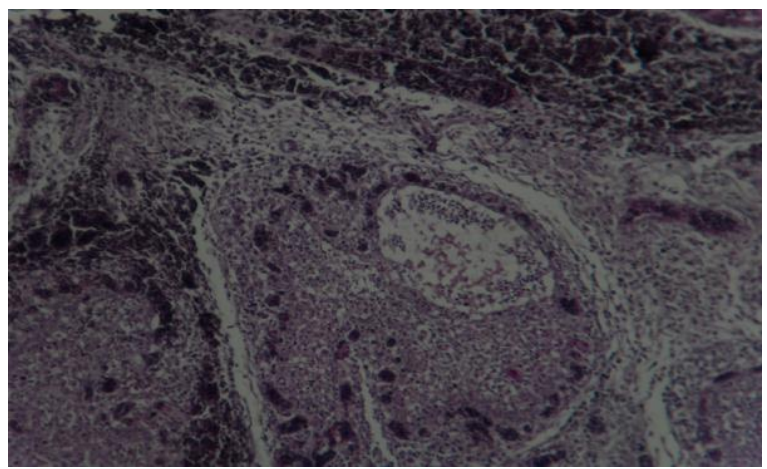

Fig. 7 Sometimes, in the medullary zone of follicles, cystic cavities could be formed that contain exudate, inflammatory cells and necrotic debris (H\&E 40X).

\section{Detection of viral RNA by RT-PCR:}

The RT-PCR technique does detection of viral RNA and it was found that the positive results were line 1 and 3 which are 643bp, (Fig. 8).

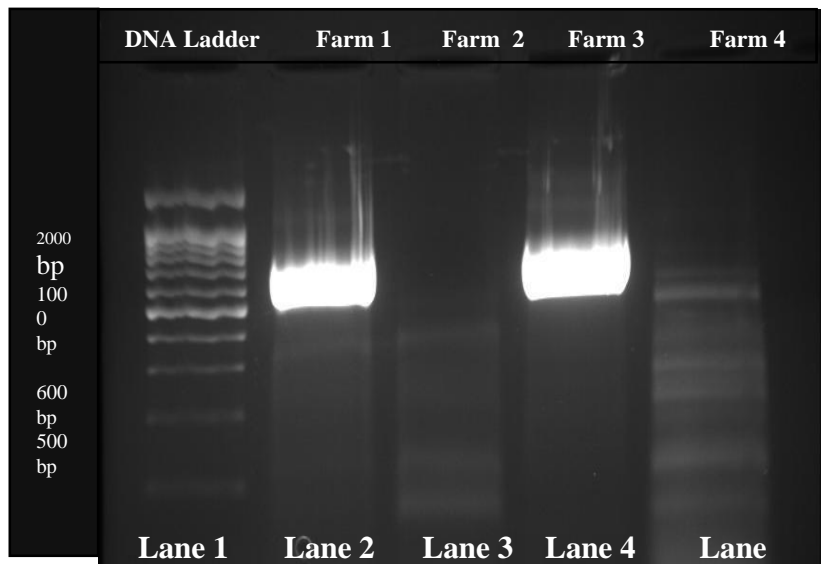

Fig.8 Shows positive results of IBDV by RT-PCR. Lane 1 is $100 \mathrm{bp}$ DNA ladder. Lane 2 and 4 (Farm 1 and 3) are 643 bp positive results. Lane 3 and 5 (Farm 2 and 4) are negative results.

The nucleotide sequence of Sulaimani IBDV isolates showed \%99 homology and they also showed \%96-\%99 similarity with other IBDV strains. Analysis of 595 nucleotide sequences of VP2 gene IBDV isolates included in this research from 633 to 1228 indicate 51 nucleotide changes in 
different loci. Both Sulaimania isolates showed nucleotide substitution with all other IBDV isolates in A843G, C948T, C1023T, C1068T, 1068T, 1011A, and 1146G. However; only Sulaimania 022012 showed a nucleotide change at A963G and $\mathrm{C} 1164 \mathrm{~T}$ as compared with other isolates including Sulaimania 01 2012. Sulaimania isolates also showed differences in nucleotide position C1173T. Sulaimania isolates have genetic characteristics of very virulance reference strain K66-1 AJ318896 at (779G, 827A, 830T, 897A, 1011A, and1094G). The genomic sequence identity of both Sulaimani IBVH isolates has indicated that there is a high similarity with very virulent IBDV strain from \%96-\%99. Sulaimani IBVH isolates have 5 conserve characteristic nucleotides of vvIBDV reference strain (UK-661).

Regarding phylogenetic tree construction based on the VP2 hypervariable region of IBDV nucleotide sequence alignment of the 16 genomes (Fig.8), the isolates were distinctly divided into two general groups, namely Very virulent 1 (VVI) and Very virulent two (VVII. The topology of the tree indicated that the field isolates Sulaimania 01, 2012, and Sulaimania 02, 2012 belong to very virulent IBDV strains that contain Indian and Egyptian Isolate. According to phylogenic tree analysis, both Sulaimani IBDV isolates clustered together in one common ancestor with vvIBDV of Indian and Egyptian IBDV, which mean they had the same genomic evolution [28]. On the other hand, genomics of Sulaimani isolate indicates seven substitution changes with another isolate of the countries may reflect the change in the pathogenicity of the Sulaimani isolate.
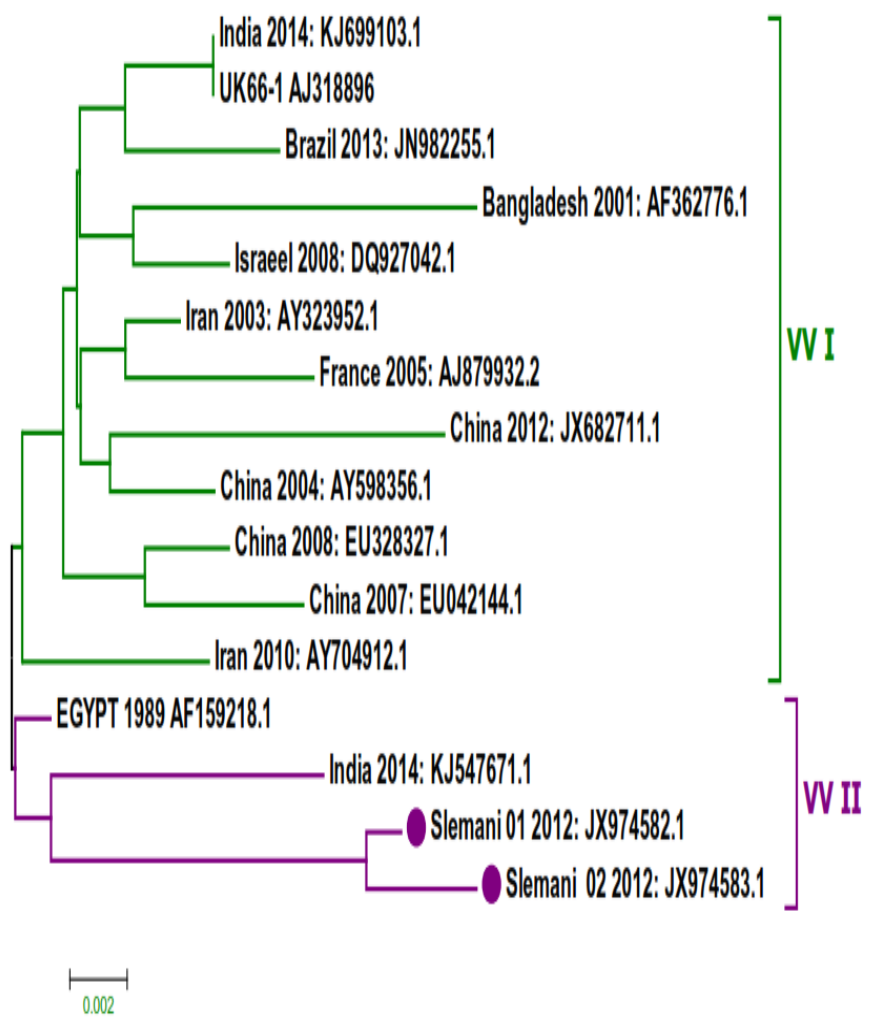

Fig. 9 Phylogenetic tree of IBDV based on VP2 gene indicated two common ancestor root of very virulent IBD

\section{CONCLUSION}

Our conclusion that there are virulent strains of Infectious bursal disease virus, which consider one of the major causative of economic loss in our country, and it need more study in order to control this diseases by quite vaccine and put good program of vaccine.

\section{ACKNOWLEDGMENT}

We would like to thanks Dr.Peshnyar M. A. Rashid for his help, and many appreciate to Micro Vet Diagnostic Lab., university of Sulaimania, college of veterinary medicine.

\section{REFERENCES}

[1] A. S. Cosgrove, "An Apparently New Disease of Chickens, Avian Nephrosis". Avian Dis. J., vol., 6, pp. 385-389, 1962. http://dx.doi.org/10.2307/1587909

[2] P. D., Lukert, and Y. M., Saif, "Infectious bursal disease. In Diseases of Poultry", 11th Ed. Ames: Iowa State University Press, pp. 161-179, 2003.

[3] P., Dobos, L., Berthiaume, J. A., Leong, F. S., Kibenge, H., Müller, and B. L., Nicholoson, " Family Birnaviridae. In Virus taxonomy", Eds F. A., Murphy, C. M., Fauquet, D. H. L., Bishop, S. A., Gabriel, A. W., Arvis, G. P., Martielli, M O., Mayo, M. D., Summers, Springer-Verlag, Vienna, Austria, pp 240-244, 1995.

[4] H., Müller, and R., Nitschke, "The Two Segments of the Infectious Bursal Disease Virus Genome are Circularized by a 90000-Da Protein", Virol. J. , vol. 159, pp. 174-177, 1987.

http://dx.doi.org/10.1016/0042-6822(87)90363-1

[5] E., Mundt, J., Beyer, and H., Müller, "Identification of a Novel Viral Protein in Infectious Bursal Disease Virus-Infected Cells", Gen. Virol. J. , vol. 76, pp. 437-443, 1995.

http://dx.doi.org/10.1099/0022-1317-76-2-437

[6] P. J., Hudson, N. M., McKern, B. E., Power, and A. A., Azad, "Genomic Structure of the Large RNA Segment of Infectious Bursal Disease Virus", Nucleic Acids Reso, vol. 14, pp. 5001-5012, 1986. http://dx.doi.org/10.1093/nar/14.12.5001

[7] K. J., Fahey, K., Erny, and J., Crooks, "A Conformational Immunogen on VP2 of Infectious Bursal Disease Virus that Induces VirusNeutralizing Antibodies that Passively Protect Chickens" Gen. Virol. J. , vol. 70, pp. 1473-1481, 1989. http://dx.doi.org/10.1099/0022-1317-70-6-1473

[8] A. A., Azad, M. N., Jagadish, M. A., Brown, and P. J., Hudson, "Deletion Mapping and Expression in Escherichia coli of the Large Genomic Segment of a Birnavirus", Virol. J., vol. 161, pp. 145-152, 1987.

http://dx.doi.org/10.1016/0042-6822(87)90180-2

[9] H., Becht, H., Müller, and H. K., Müller, "Comparative Studies on Structural and Antigenic Properties of Two Serotypes of Infectious Bursal Disease Virus", Gen. Virol. J. , vol. 69, pp. 631-640, 1988. http://dx.doi.org/10.1099/0022-1317-69-3-631

[10] F.S.B., Kibenge, P.K., Mckenna, and J.K., Dybing, "Genomic Cloning and Analysis of the Large RNA Segment (segment A) of a Naturally Avirulent Serotype 2 IBDV", Virol. J. , vol. 184, pp. 437-440, 1991. http://dx.doi.org/10.1016/0042-6822(91)90865-9

[11] N. M., Ismail, and Y. M., Saif, "Differentiation Between Antibodies to Serotype 1 and 2 Infectious Bursal Disease in Chicken Sera", Avian Dis. J., vol. 34, pp. 1002-1004, 1990. http://dx.doi.org/10.2307/1591396

[12] D. J., Jackwood, and R. J., Jockwood, "Infectious Bursal Disease Viruses: Molecular Differentiation of Antigenic Subtypes among Serotype 1 virus", Avian Dis. J., vol. 38, pp. 531-537, 1994. http://dx.doi.org/10.2307/1592075

[13] H., Müller, M. R., Islam, and R., Raue, "Research on Infectious Bursal Disease: the past, the present and the future", Vet. Microbio. J., vol. 97, pp. 153-165. 2003. http://dx.doi.org/10.1016/j.vetmic.2003.08.005

[14] S., Juneja, S., Ramneek, D., Deka, M. S., Oberoi and A., Singh, "Molecular Characterization of Field Isolates and Vaccine Strains of 
Infectious Bursal Disease Virus", Comp. Immunol. Microbiol. Infec.

Dis., vol. 31, pp. 11-23, 2008.

http://dx.doi.org/10.1016/j.cimid.2007.03.001

[15] J. B., McFerran, M. S., McNulty, E. R., Killop, T. J., Connor, R. M., McCracken, P. S., Collins, and G. M., Allan, "Isolation and Serological Studies with Infectious Bursal Disease Virus from Fowl, Turkeys and Ducks: Demonstration of a Second Serotype", Avian Pathol. J., vol., 9, pp. 395-404. 1980. http://dx.doi.org/10.1080/03079458008418423

[16] D. J., Jackwood, Y. M., Saif, and J. H., Hughes, "Characteristics and Serologic Studies of two Serotypes of Infectious Bursal Disease Virus in Turkeys", Avian Dis. J., vol., 26, pp. 871-882. 1982. http://dx.doi.org/10.2307/1589875

[17] D. B., Snyder, P. , K., Lana, F. S., Savage, S. A., Yancy Mengel, and W. W., Mardquart, "Differentiation of Infectious Bursal Disease viruses Directly from Infected Tissues with Neutralizing Monoclonal Antibodies: Evidence of a major Antigenic Shift in a Recent Field Isolates", Avian Dis.J.,vol., 32, pp. 535-539, 1988. http://dx.doi.org/10.2307/1590924

[18] M. Y., Wang, H. L., Hu, S. Y., Suen, F. Y., Chiu, J. H., Shien and Lai, S. Y., "Development of an Enzyme-linked Immunosorbent Assay for Detecting Infectious Bursal Disease Virus (IBDV) Infection based on the VP3S Protein", Vet. Microbiol. J., vol., 131, pp. 229-236, 2008. http://dx.doi.org/10.1016/j.vetmic.2008.03.010

[19] P. D., Lukert, and Y. M., Saif, "Infectious bursal disease. In Diseases of Poultry", 11th Ed. Ames: Iowa State University Press., pp 161-179, 2003.

[20] R.C., Taylor, S.P., Cullen, and S.J., Martin, "Apoptosis: Controlled Demolition at the Cellular Level", Nat. Rev. Mol. Cell Biol J.,vol., 9, pp. 231-241, 2008. http://dx.doi.org/10.1038/nrm2312

[21] D. J., Jackwood, K.C., Cookson, S. E., Sommer-Wagner, H., Le Galludec, and J.J., de Wit, "Molecular Characteristics of Infectious Bursal Disease Viruses from Asymptomatic Broiler Flocks in Europe", Avian Dis. J., vol., 50, pp.532-536, 2006. http://dx.doi.org/10.1637/7528-032006R1.1

[22] G., Li, H.S., Lillehoj, K.W., Lee, S. I., Jang, P., Marc, C.G., Gay, G.D., Ritter, D. A., Bautista, K., Phillips, A.P., Neumann, T.G., Rehberger, G.R., Siragusa, "An Outbreak of Gangrenous Dermatitis in Commercial Broiler Chickens", Avian Pathol. J., vol., 39, pp. 247-253, 2010. http://dx.doi.org/10.1080/03079457.2010.487517

[23] M., Bublot, N., Pritchard, F.X., Le Gros, and S., Goutebroze, "Use of a Vectored Vaccine against Infectious Bursal Disease of Chickens in the Face of High-titred Maternally Derived Antibody", Comp Pathol. J., vol., 137, pp. 81-84, 2007. http://dx.doi.org/10.1016/j.jcpa.2007.04.017

[24] H.A., Mahgoub, "An Overview of Infectious Bursal Disease", Arch Virol, DOI., 10.1007/s00705., vol., 12, pp. 1377-1379, 2012.

[25] C.L., Nouën, D., Toquin, H., Müller, R., Raue, K.M., Kean, P., Langlois, M., Cherbonnel, and N., Eterradossi, "Different Domains of the RNA Polymerase of Infectious Bursal Disease Virus contribute to Virulence", PloS One, 7, pp. 28064, 2012. http://dx.doi.org/10.1371/journal.pone.0028064

[26] K., Tamura, D., Peterson, N., Peterson, N., M., Stecher Nei and S., Kumar, "MEGA5: Molecular Evolutionary Genetics Analysis using Maximum Likelihood, Evolutionary Distance, and Maximum Parsimony Methods", Molecul. Biol. and Evolu. J., vol., 28, pp. 27312739, 2011. http://dx.doi.org/10.1093/molbev/msr121

[27] H., Müller, E, Mundt, N., Eterradossi, and M.R., Islam, "Current Status of Vaccines against Infectious Bursal Disease", Avian Pathol. J., vol., 41, pp. 133-139, 2012. http://dx.doi.org/10.1080/03079457.2012.661403

[28] A. M., Moemen, K. E. S., Elzanaty, M. B., Bakhit, and M. S., Marwa, "Genetic Characterization of Infectious Bursal Disease Viruses Associated with Gumboro Outbreaks in Commercial Broilers from Asyut Province", Egypt. 9, 2014. 